\title{
Web 2.0 Uygulamalarinin Eğitim Süreçlerine Etkisi: Çanakkale Sosyal Bilimler Meslek Yüksekokul Örneği*
}

\author{
Dilek Kekeç MORKOÇ
}

\section{Cumhur ERDÖNMEZ}

ÖZET Ö̆gretim alanında kullanılan metodolojilerin çă̆̆mızın vazgeçilmez bir tutkusu haline gelen teknolojinin hızına paralel gelişimi ile birlikte tek yönlü iletişim süreci olan Web 1.0 yerine, içeriğin değiştirilebildiği, gelişstirilebildiği Web 2.0 kullanılmaya başlanmıştır. Günümüzde birçok sosyal ă̆ sitesi ortaya çıkmış ve bu sosyal ağların kullanımı özellikle genç kullanıcılar arasında hızla artış göstermeye başlamıştır. Web 2.0 uygulamaları her türlü bilgiyi ve öğretim içeriğini kolay ve hızlı ulaşılabilir bir platforma taşıyabilmektedir. Yapılan çalışma ile Çanakkale Onsekiz Mart Üniversitesi, Çanakkale Sosyal Bilimler Meslek Yüksekokulu 20132014 eğitim-öğretim yılı (bahar) II. yarıyllında, Çanakkale Sosyal Bilimler Meslek Yüksekokulunda tüm programlarda 1. ve 2. sinıf okumakta olan 1140 öğrenci alınmıştır. Bu ana kütleden ulaşılabilen 651 kişilik bir örneklem (\% 57) oluşturulmuş ve araştırmaya katılımları sağlanmıştır. Çalışmada Beril Akıncı Vural ve Mikail Bat'ın "Sosyal Medya Kullanım Bilgileri Detaylandırılarak Hangi Sosyal Ağları Kullandıkları" ve Kullanım alışkanlıklarımı" saptanmaya yönelik anket çalışmaları ile Onyebuchi tarafından 2009 yılında gerçekleştirilen "Sosyal Medyanın Öğrenim ve Öğretim Süreçlerine Etkisini Belirleme" amaçlı hazırlanan anket referans alınmıştır. Çalışmaya katılan öğrencilerinin bilgi iletişim teknolojilerinden internet ve sosyal medya kullanım alışkanlıklarını, sosyal medya bilgi düzeylerinin saptanmasına ve üniversite düzeyindeki eğitim süreçlerinde sosyal medyanın kullanımının etkililiği ve faydalanabilirliğinin tespiti amaçlanmıştır.

Anahtar Kelimeler: Web 2.0, Sosyal A ̆g, Eğitim, Meslek Yüksekokulları 


\title{
The Using Of Web 2.0 Technology in the Training Processes:
}

\section{A Sample for the College of Çanakkale Social Sciences}

\begin{abstract}
Instead of Web 1.0 , which is one-way communication process of the methodologies used in teaching together with the pace of technology, which has become an indispensable passion of our age including the parallel development, Web 2.0, the content of which can be changed and developed, has been used. Today, many social networking sites have emerged, and the use of these social Networks, especially among younger users, have began to increase rapidly. The Web 2.0 applications are able to carry all kinds of information and training content to an easily and quickly accessible platform. The use of Web 2.0 technology field is rapidly expanding each passing day. In the light of studies carried out, Çanakkale Onsekiz Mart University, Çanakkale Vocational School of Social Sciences have registered 1140 students majoring in the 1st and 2nd grades of all programs in 2013-2014 academic year ( spring ) II. semester. A sample of 651 persons (57\%) from this main mass accessed has been formed and provided their participations in the research. In this study, by being detailed Beril Akıncr Vural and Mikail Bat's "Social Media Usage Information, a survey study to be determined what Social Networks they use and their usage habits and also, a survey purposed Specifying the" Effects of the Social Media to Learning and Teaching Process " carried out by Onyebuchi in 2009 has been taken as reference. Through information and communication Technologies, their internet and social media usage habits, determination of their social media level of knowledge and determination of the effectiveness and credibility of the use of social media in their educational processes at university-level of the students involved in the study have been intended.
\end{abstract}

Keyword: $\quad$ Web 2.0, Social Networking, Education, Vocational Schools

\section{Giriş}

Sosyal medya kavramı; medya, kullanıcı ve teknoloji gibi boyutları olan bir kavramdır. Sadece bir boyut ile sosyal medyayı değerlendirmek eksik ve yanlış olacaktır. Sosyal medya tüm bu boyutlarının bütünleşik bir şekilde ele alınması ile anlaşılacaktır. Sosyal medyanın medya boyutu, geleneksel medyadan farklı özelliklere sahip yeni medya ile açıklanırken, kullanıcı boyutu kullanıcı tabanlı içerik ve teknoloji boyutu Web 2.0 ile açıklanmaktadır (İşlek, 2012:5). Sosyal medya, en basit tanımıyla; Web 2.0 teknolojilerinin kullanıldığı iletişim ortamlarıdır. Konuşmalar, bağlantılar ve katılımlardan kaynaklanan Web 2.0 durakları, iletişim araçları, siteleri ve çevrimiçi yayınlar (Gunelius, 2011:10; akt: İşlek, 2012: 12) olarak da tanımlanan sosyal medya; insanların sosyalleşmek için kullandıkları medya türüdür.

Sosyal medyanın ortaya çıkışı, her şeyden önce Web teknolojilerindeki değişime dayanmaktadır. İnternet 1960'lı yıllarda gelişmeye başlasa da, world wide web (dünyayı 
saran ağ) 1989-91 yılları arasında Dr. Tim Berners-Lee tarafından geliştirilmiştir. Internet'in gelişimi sonrasında bazı yazarlar kullanıcıların serbestçe bilgiyi tarayabilecekleri, birbiriyle bağlantılı sayfaların oluşturulabileceği fikrini ortaya atmışlardı. Bu fikirlerden hareketle Berners-Lee ve ekibi web'in en temel dört unsuru olan html, http, bir web server ve bir tarayıcının (browser) ilk versiyonu oluşturulmuştur. Oluşturulan ilk web sayfaları, siyahbeyaz ve tamamen metne dayalı bir yapıdadır. Bu dönemde ortaya çıkan web siteleri de temelde bilgi verme amacını taşımıştır. Web 1.0 diye adlandırılan bu dönemde oluşturulan web siteleri, statik bir yapıya sahip olan ve sadece okumaya elverişli sayfalardır. Okuyucuların bu sayfalar üzerinden web sitesinin sahibiyle ya da birbirleriyle etkileşime girmesi mümkün değildir. Web 1.0 dönemi, etkileşimin olmadığı, dolayısıyla kullanıcının söz hakkının bulunmadığı ve tek taraflı bilgi aktarımının olduğu bir ortamı ifade etmektedir ( http://eogrenme.anadolu.edu.tr/). Web 1.0 ile gelişimine başlayan web; web 2.0 ile internet kullanıcılarının tek taraflı iletişimi bırakıp, içeriği değiştirebildikleri konuma geldikleri noktadır (Bozkurt,2013). Web 2.0 kavramı world wide web (www)'in ikinci kuşağını tanımlamak için kullanılmaktadır. Bu kavram ilk kuşak web araçlarından farklı özelliklere sahip araçları tanımlamada kullanılmaktadır (Horzum, 2010: 605). Web 2.0 tabanlı ortamlar, sunucularda barındırılan ve internet aracılığı ile tarayıcılarda görüntülenen bireysel sistemlerdir. Bu yüzden bu ortamlar Web 2.0 sistemleri, Web 2.0 servisleri ya da Web 2.0 uygulamaları olarak da adlandırılabilmektedirler. Tüm bu adlandırmalar ise bu ortamların grup çalışmalarına olan yatkınlığından dolayı sosyal yazılım etiketi altında toplanmaktadır. Ancak, son zamanlarda sosyal yazılım kavramı yerini sosyal medya kavramına vermiştir (Duffy, 2008; akt:Mıcık, 2011: 19). Yapılan çalışmalarda web 2.0 kavramının sosyal medya kavramıla eşanlamlı olarak kullanıldığı görülmektedir (Lenhart, Purcell, Smith, \& Zickuhr, 2010; akt: Baran, Ata, 2013: 195).

Web 2.0 kavramı ilk olarak 2004 yılında, Dale Dougherty ve Tim O'Reilly ve MediaLive International1 tarafından organize edilen, Google, Yahoo, Msn, Amazon, Ebay gibi Web dünyasının önde gelen şirketlerinin de katıldığı web konferansında, web alanında yaşanan gelişmeler ve web dünyasının geleceği konusunda tartışılırken ortaya çıkmıştır (www.bidb.itu.edu.tr). Web 2.0 uygulamalarıyla birlikte ortaya çıkan araçlardan en önemlilerinden birisi de çevrimiçi sosyal ağlardır (Boyd ve Ellison, 2007, akt: Uçak, Çakmak, 2010: 44). Sosyal ağ, ingilizcede "social network" bireylerin birbirlerine çeşitli ilişkilerle bağlı olduğu bir yapıyı temsil eder. İlk sosyal site 1997 de kurulan "Sixdegrees.com" dur ve kullanıcılarına ilk kez profil oluşturabilme ve mesaj gönderme olanağı sağlamıştır. 2001'den itibaren ortaya çıkan Asianavenue, Blackplanet, Migente ve Cyworld etkili bir politika uygulamış ve arkadaşlık ilişkilerine daha farklı boyutlar eklemişlerdir. 2004 ve sonrasında ise internet kullanıcıları Myspace, Facebook ve Bebo ile tanışmışlardır (http://e-

\footnotetext{
${ }^{1}$ (Uluslararası konferans, fuar ve toplantılar düzenleyen Amerikan şirketi)
} 
bergi.com/2007/Aralik/Social-Network ). Sosyal ağlar, herkes tarafından erişilebilen veya belirli bir kullanıcı kitlesi ile sınırlandırılmış bir sistem içinde kullanıcı profili oluşturma, diğer kullanıcıların belirttiği bağlantıları görebilme ve paylaşma olanağı sağlayan web tabanlı hizmetler olarak tanımlanmaktadır (Boyd ve Ellison, 2007, akt: Uçak, Çakmak, 2010: 44). Web 2.0, web hizmetini iyileştirmek amacıyla ziyaretçilerin siteye katılımını (participation) sağlamak, yine aynı amaçla diğer sitelerle ve ziyaretçilerle işbirliği (collaboration) yapmak fikrine dayanan bir akım olduğu da söylenebilir. Web 2.0 teknolojisinin klasik örneği, kullanıcıların etkileşimli oldukları ve içeriği yarattıkları sosyal ağlar ve güçlü işbirliği olarak online ansiklopedi Wikipedia'dır (Gross ve Leslie, 2008: 791; akt: Vural, Bat: 2010 3354) ). Web 2.0 teknolojileri içinde genel olarak birçok farklı uygulama da mevcuttur. En çok kullanılan uygulamalardan bazıları olarak Facebook, YouTube, MySpace, Linkedin, Twitter, Google uygulamaları, wikipedia, blog sayfaları sayılabilir. Sosyal medya araçları olarak adlandırılan web 2.0 teknolojilerinin uygulamalarında içeriği tamamen bireyler belirler ve bireyler birbirleri ile sürekli bu uygulamalar üzerinden etkileşim halindedir. Kısacası zaman ve mekân sınırlaması olmaksızın paylaşımın, etkileşimin ve tartışmanın esas olduğu bir iletişim şeklidir (Erkul, 2009: 3). Web 2.0 teknolojileri sayesinde kullanıcılar bilgilerini metin olarak paylaşmanın yanı sıra fotoğraflarını, videolarını ve ses dosyalarını da paylaşma imkanına erişmektedirler. Ses ve görüntüleme aygıtlarının ucuzlamasıyla milyonlarca insan kendi medyasını yaratıp yayınlamaktadırlar. Multimedya paylaşımının artmasıyla sadece paylaşım için özelleşmiş sitelerin sayısı da artmaya başlamıştır. Bunlar içinde en bilinenleri Youtube (video), Flickr (fotoğraf) ve Odeo (podcast) siteleridir (Durusoy, 2011: 23). Web 2.0 standartlarını kullanarak üretilen teknolojiler arasında paylaşımın ve etkileşimin en önemli etkinlik olduğu ortamlar sosyal ağlardır. Şu anda dünya üzerinde en çok ziyaretçi çeken sitelere bakıldığında sosyal ağların üst sıralarda yer aldığı görülmektedir İlk olarak 1997 yılında Six.Degrees.com sosyal ağının kurulmasının ardından bunu Livejournal, Friendster, Myspace gibi popüler sosyal ağlar izlemiştir. Son olarak 2004 yılında kurulan Facebook çok kısa zamanda büyük bir kullanıcı popülasyonuna ulaşmıştır (Durusoy, 2011: 24).

Eğitimcilerin, araştırmacıların, öğrencilerin kolaylıkla ve çoğunlukla ücretsiz ulaşabilecekleri blog, podcast, sosyal ağlar gibi ikinci nesil internet teknolojileri (web 2.0), eğitimde yeni olanaklar sunmaya başlamıştır (Rhoades et al., 2009; Williams and Chinn, 2009; akt: Micık, 2011: 26). Web 2.0 tabanlı ortamların işbirlikli çalışmayı, bilgiye erişim, sosyal etkileşimi, geri bildirimi oldukça kolay hale getirmesi, eğitim alanında kullanılmalarına ön ayak olmuştur (McLoughlin and Lee, 2007; akt: Micık, 2011: 26). Eğitim alanında yürütülen çalışmalarda sıklıkla kullanılan Web 2.0 teknolojilerinin blog, wiki, podcast, video paylaşım siteleri ve sosyal ağlar olduğu söylenebilir (Davies \& Merchant, 2008; Griffiths \& Wall, 2011; Kuzu, 2007; Meyer, 2010; Usluel \& Mazman, 2009; akt: Baran, Ata, 2013: 195). Web 2.0' in getirmiş olduğu uygulamalar birçok eğitimsel amacın gerçekleştirilmesinde kullanılabilir. Bu 
uygulamaların hangi amaçlarla kullanılabileceğine dair örnekler aşağıdaki tabloda belirtilmiştir (Grosseck, 2009: 478:akt: Durusoy, 2011: 24)

Tablo 1: Web 2.0 Uygulamalarının Eğitimde Kullanımı

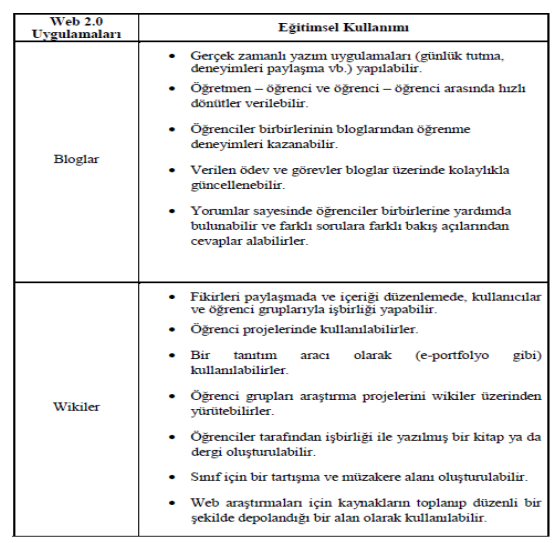

\begin{tabular}{|c|c|}
\hline $\begin{array}{c}\text { Resim / Fotoğraf } \\
\text { Paylaşıı }\end{array}$ & 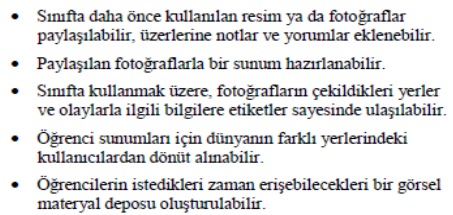 \\
\hline Video Paylaşımı & $\begin{array}{l}\text { - Öğretmenler kendi başlarına ya da ögrenciler ile birlikte } \\
\text { kendi ögretimsel videolarını çekip paylaşabilirler. } \\
\text { - Video paylaşım sitelerinden çok sayıda ögretici videoya } \\
\text { ulaşılabilir. }\end{array}$ \\
\hline RSS Kullanımı & $\begin{array}{l}\text { - Öğretim ortamlarında zaman tasarnufu ve güncel bilgile } \\
\text { sayesinde profesyonel içerik gelişimi sağlar. } \\
\text { - Erişimi zor kaynaklardan bilgi akışı sağlanabilir. }\end{array}$ \\
\hline Sosyal Ağlar & $\begin{array}{l}\text { - Sosyal medya ve kişisel oğrenme uygulamalarını bir çat } \\
\text { altunda toplar. } \\
\text { - Bağlantılar sayesinde grupların diğer oğretimsel Web } 2.0 \\
\text { uygulamalarna tek bir kaynaktan ulaşmalarmı sağlar. }\end{array}$ \\
\hline
\end{tabular}

Web 2.0 uygulamaları her türlü bilgiyi ve öğretim içeriğini kolay ve hızlı ulaşılabilir bir platforma taşıyabilmektedir. Web 2.0 teknolojilerinin kullanım alanı her geçen gün hızla genişlemektedir. Bu durumun başlıca nedenleri, Web 2.0 teknolojilerinin, kullanıcı ve web uygulamaları arası etkileşimi, kullanıcılar arası etkileşimi, işbirlikçi çalışmaları ve bilgiye erişimi, internet ortamında "oldukça kolay" bir hale gelmesidir. Söz konusu bu özellikler web 2.0 teknolojileri ve standartlarının eğitim alanında kullanılmasına ön ayak olmuştur (Deperlioğlu, Köse, 2010: 338). Örneğin Youtube internet sitesinin kurmuş olduğu "youtubeedu"2 sistemi sayesinde ABD'deki üniversiteler ve eğitim kurumları ders içeriklerini ve üniversite tanıtımlarını burada kurdukları kanallar üzerinden yapmaya başladılar. Bu kanallarda seyrettiğiniz video dersler ve eğitim materyalleri ile ilgili yorum yapabilme imkânınız da var. Örneğin seyrettiğiniz bir ders ile ilgili görüş ve sorularınızı kullanıcı olarak diğer kullanıcılar ile paylaşabiliyorsunuz (http://www.digitaldevlet.org). Web 2.0 araçlarıyla daha etkili bir öğrenme sağlamak için kullanabileceği bir diğer uygulama da, "google jokey" uygulaması olabilir (Bonk, 2009). Özellikle öğrencilerden biri sunum yaparken başka bir öğrenciyi de 'google jokey' olarak seçme mantığına dayanmaktadır, 'google jokey' olarak seçilen öğrenci sunumda kullanılan ve anlaşılmayan kavramlar, fikirler ve web siteleri ile ilgili ek bilgiler sağlamaktadır. $\mathrm{Bu}$, sunum esnasında olabileceği gibi bunları öğrencinin not alıp bir sonraki derste açıklaması şeklinde de uygulanabilir (Elmas, Geban, 2012:250). Web 2.0 uygulamaları eğitim, sosyal ağ, paylaşım gibi birçok farklı uygulama da mevcut olduğu görülmektedir.

${ }^{2} \mathrm{http}: / /$ www.youtube.com/education?b=1 
Çalışmanın amacı, öğrencilerin bilgi iletişim teknolojilerinden, internet ve sosyal medya kullanım alışkanlıklarını, sosyal medya bilgi düzeylerinin saptanması ve üniversite düzeyindeki eğitim süreçlerinde, sosyal medyanın kullanımının etkililiği, faydalanabilirliğini tespit etmek ve eğitim süreçlerine etkisini belirlemektir.

\section{Yöntem}

Çanakkale Onsekiz Mart Üniversitesi, Çanakkale Sosyal Bilimler Meslek Yüksekokulu öğrencilerinin bilgi iletişim teknolojilerinden internet ve sosyal medya kullanım alışkanlıklarını, sosyal medya bilgi düzeylerinin saptanmasına ve üniversite düzeyindeki eğitim süreçlerinde, sosyal medyanın kullanımının etkililiği ve faydalanabilirliğinin tespitine ilişkin yapılan bu çalışmada, Genel Tarama Modeli esas alınmıştır. Tarama Modeli, bir olay ya da durumu var olduğu şekliyle betimlemeyi amaçlayan modeldir. Var olan olay ya da durum, kendi koşulları içinde ve olduğu şekliyle tanımlanır (Karasar,1999). Genel tarama modelleri ise, çok sayıda elemandan oluşan bir evrende, evren hakkında genel bir yargıya varmak amacı ile evrenin tümü ya da ondan alınacak bir grup, örnek ya da örneklem üzerinde yapılan tarama düzenlemeleridir. Bu nedenle çalışma da genel tarama modeli esas alınmıştır.

\section{Katilımcilar}

Araştırmanın katılımcları, 2013-2014 eğitim-öğretim yılı bahar (II.) yarıyılında Çanakkale Onsekiz Mart Üniversitesi, Çanakkale Sosyal Bilimler Meslek Yüksekokulunda okumakta olan 1. ve 2. sınıf öğrencileridir. Çalışmanın ana kütlesi 1140 öğrenci oluşturmaktadır. Bu ana kütleden ulaşılabilen 651 kişilik bir örneklem (\% 57) oluşturulmuş ve araştırmaya katılımları sağlanmıştır. Çalışma Meslek Yüksekokulunda hale hazırda eğitim ve öğretim yapılan, Büro Yönetimi ve Yönetici Asistanlığı, Yerel Yönetimler, Halkla İlişkiler, İşletme yönetimi, Çocuk Gelişimi, Muhasebe ve Vergi Uygulamaları programıdır.

\section{Ölçme Aracı}

Çalışmada Beril Akıncı Vural ve Mikail Bat'ın (2010) "Yeni Bir İletişim Ortamı Olarak Sosyal Medya: Ege Üniversitesi İletişim Fakültesine Yönelik Bir Araştırma" başlıklı çalışmadan yararlanılmıştır. Birinci bölümde öğrencilerin internet kullanım bilgilerine ulaşılmaya, ikinci bölümde öğrencilerin sosyal medyadan haberdar olup olmadığını ve eğer haberdar ise sosyal medya kullanım alışkanlıklarını, üçüncü bölümde ise daha çok sosyal medya kullanım bilgilerini detaylandırarak hangi sosyal ağları kullandıkları ve kullanım alışkanlıklarının derecesini saptamaya çalışılmıştır. Anket toplam 22 sorudan (10 tanesi kapalı uçlu olarak evet ve hayır seçeneklerinden) oluşmaktadır. (Vural, Bat: 2010).

Çalışmada ayrıca, Abdullah Toğay vd. (2013:303) "Eğitim Süreçlerinde Sosyal Ağların 
Kullanımı: Bir MYO Deneyimi" başlıklı çalışmasında kullanılan Onyebuchi3 (2009) tarafından gerçekleştirilen "sosyal medyanın öğrenim ve öğretim süreçlerine etkisini belirleme" amacıyla hazırlanan anket referans alınmıştır. İlgili anketin "Sosyal Medya"'ya ilişkin bölümleri kullanılmıştır. Çalışmada kullanılan anket; Sosyal Medyanın Eğitim Süreçlerindeki Önemi, Sosyal Medyanın Eğitimde Kullanımını Etkileyen Faktörler, Sosyal Medyayı Eğitimde Kullanmaya Yönelik Tutumlar, Eğitim Süreçlerinde Sosyal Medyanın Kullanım Sıklığı, Eğitim Süreçlerinde Kullanılan Sosyal Medya Araçları, Eğitim Süreçlerinde Kullanılan Sosyal A $\breve{g}$ Web Siteleri, Sosyal Ağ Web Sitelerinin Kullanım Amaçları başlıklarıyla yedi bölümden oluşmaktadır. Anket toplam 25 sorudan oluşmaktadır. (Toğay vd. 2013: 303).

\section{Verilerin Analizi}

Anketle toplanan verilerin güvenilirliği ve geçerliliği, veri toplamada kullanılan bu tekniğin özellikleri ile sınırlıdır. Ölçek geliştirme aşamasında taslak ölçek formuna ait verilerin analizleri için SPSS 16.0 programında değerlemeye alınmış ve analize tabi tutulmuştur. Verilerin rastlantısallığını ölçmek ve ölçeğin analiz yapmaya uygun olup olmadığını test etmek için güvenilirlik analizinden yararlanılmıştır. Kişisel bilgilerin dağılımına bakmak için frekans ve yüzde analizleri çıkarılmıştır. Ayrıca, ortalama skorların normal dağılım gösterip göstermediği Kolmogorov-Smirnov ve Shapiro-Wilk istatistiklerine göre araştırılmıştır. Skorların normal dağılmadığı belirlenmiş ve farklılıklar araştırılırken parametrik testler yerine nonparametrik testlerden Mann-Whitney $U$ testi yapılmış ve elde edilen sonuçlar değerlendirilmeye çalışılmıştır.

\section{Bulgular ve Yorumlar}

Güvenilirlik analizinin amacı verilerin rastlantısallığını ölçmektir. Ankete verilen cevaplar rastgele dağılım gösteriyorsa anket sonuçlarının güvenilir olduğuna karar verilir. Güvenilirlik analizi seçilen örneğin güvenilirliğini, tesadüfîliğini ve tutarlılığını test etmekte kullanılır. Sonucun güvenilir olup olmadığına Cronbach's Alpha $(\alpha)$ değerine göre karar verilir (Sağır, 2011: 91).

- $0,00 \leq \alpha<0,40$ ise güvenilir değildir

- $\quad 0,40 \leq \alpha<0,60$ ise düşük güvenilirliktedir.

- $0,60 \leq \alpha<0,80$ ise oldukça güvenilirdir.

\footnotetext{
${ }^{3}$ Onyebuchi, E. E., "Making Sense of Web 2.0 Technology: Do European Students Use The Social Media Applications For Educational Goals?", Master's Thesis in Communication Studies, http://essay.utwente.nl/59499/1/scriptie_E_Eze.p df, (2009)
} 
- $\quad 0,80 \leq \alpha \leq 1,00$ ise yüksek derecede güvenilirdir.

Tablo 2: Güvenirlik Analizi

\begin{tabular}{|c|c|}
\hline $\begin{array}{c}\text { Cronbach's } \\
\text { Alpha }\end{array}$ & Madde Sayısı \\
\hline, 929 & 22 \\
\hline
\end{tabular}

Öğrencilerin bilgi iletişim teknolojilerinden, internet ve sosyal medya kullanım alışkanlıklarını, sosyal medya bilgi düzeylerinin saptanması ve üniversite düzeyindeki eğitim süreçlerinde, sosyal medyanın kullanımının etkililiği ve faydalanabilirliğinin tespit edilmesinin çalışıldığı araştırmada, Onyebuchi (2009) tarafından gerçekleştirilen "sosyal medyanın öğrenim ve öğretim süreçlerine etkisini belirleme" amaçlı hazırlanan 22 maddelik ölçeğin güvenilirliği araştırılmış, ölçekte ölçeği bozan herhangi bir soruya rastlanılmamıştır. Ölçeğin güvenilirlik katsayısı $\alpha=0,929$ bulunmuştur. Ölçek güvenilirdir. Ayrıca, örnek hacmi analizimiz için oldukça yüksek derecede güvenilir düzeydedir. Yapılan çalışmanın anket sonuçlarına ilişkin verilere bakıldığında toplam 1140 öğrenciye anket uygulanması hedeflenmiş, ancak 651 öğrenciye (\%57) uygulanabilmiştir. Çalışmaya katılan öğrencilerin \%66,2 (431) kız, \%33,8 'i (220) ise erkek öğrencilerdir. Öğrencilerin yaşları incelendiğinde; \%64,1'i (18-20) yaş aralığında, \% 34,6'si (21-24) yaşa aralığında, \%0,8'i (25-30) yaşa aralığında iken \%0,5'i (3) de 31 yaş ve üstü olarak tespit edilmiştir. Öğrencilerin okudukları bölümlere göre katılım oranları ise şöyledir.

Çanakkale Sosyal Bilimler Meslek Yüksekokulundaki Muhasebe ve İşletme Bölümü öğrenci kontenjan sayısı 60 diğer bölümlerin kontenjanları 40 kişidir. Büro Yönetiminden çalışmaya katkı sağlayan öğrenci sayısı 106 (\%16), Halkla İlişkiler Bölümünde katılımcı sayısı 54 (\%8,3), Yerel Yönetim katılımcı öğrenci sayısı 118 (\%18,1), Muhasebe bölümü katılımcı sayısı 158 (\%24,2), Çocuk gelişimi öğrencileri 73 (\%11,1) ve işletme bölümü katılımcı sayısı $142(\% 21,8)^{\prime}$ dir. Sonuçlar tablo 3'de verilmiştir.

Tablo 3: Katılımcıların Okumakta Oldukları Bölümler

\begin{tabular}{|l|l|l|l|l|l|}
\hline Bölümler & $f$ & $\%$ & Bölümler & & \\
\hline Büro1 gündüz & 28 & 4,3 & Muh 1 gündüz & 38 & 5,8 \\
\hline Büro1 gece & 26 & 4,0 & Muh 1 gece & 23 & 3,5 \\
\hline Büro gündüz 2 & 25 & 3,8 & Muh 2 gündüz & 7,7 \\
\hline
\end{tabular}




\begin{tabular}{|c|c|c|c|c|c|}
\hline Büro 2 gece & 27 & 4,1 & Muh 2 gece & 47 & 7,2 \\
\hline Yerel 1 gündüz & 37 & 5,7 & Işletme 1 gündüz & 43 & 6,6 \\
\hline Yerel 1 gece & 29 & 4,5 & Işletme 1 gece & 35 & 5,4 \\
\hline Yerel 2 gündüz & 27 & 4,1 & İşletme 2 gündüz & 37 & 5,7 \\
\hline Yerel 2 gece & 25 & 3,8 & Işletme 2 gece & 27 & 4,1 \\
\hline Çocuk gelişimi 1gündüz & 25 & 3,8 & Halkla iliş.1 gündüz & 24 & 3,7 \\
\hline Çocuk gelişimi 1 gece & 25 & 3,8 & Halkla iliş. 2 gündüz & 30 & 4,6 \\
\hline Çocuk gelişimi 2 gece & 23 & 3,5 & Toplam & 651 & 100,0 \\
\hline
\end{tabular}

Öğrencilerin anket sorularına verdikleri cevaplar incelendiğinde; Öğrencilerin \%65,9 (429) ÖSS sınavı ile okula kayıtlanırken, \%34,1 (222)'i sınavsız geçiş sistemi ile gelmişlerdir. İnternet kullanıor musunuz? sorusuna \%5 hayır cevabı verirken \%99,5 öğrenci internet kullandıklarını ifade etmişlerdir. İnterneti hangi amaçla kullanıorsunuz sorusuna alınan cevaplar ise; Resmi amaçla kullanırım 438 kişi (\%67,3); download 326 (\%50,1), Bankacılık 288 (\%44,3), eğlence $202(31,0)$, Sosyal ağlar 167 (\%25,7), bilgi alışverişi (hobi, haber, ödev vb.) $133(\% 20,4)$, video izleme $122(\% 18,8)$ olarak tespit edilmiştir. Çalışmaya katılan öğrencilerin \%79,4 (517)'ü her gün interneti kullandıklarını, \%19,2 (125) haftada 3-4 gün internet kullandıklarını ayda bir iki gün kullanan katılımcı \%1,2 (8) ve 3-4 ayda bir interneti kullanırım diyen katılımcı sayısı ise \%0,2 (1)'dir.

İnternette ortalama kaç saat zaman harcadıkları sorulmuş ve alınan cevaplar incelendiğinde, öğrencilerin \%48,7'si 1-3 saat internette zaman harcadıklarının, \%23,5 (153) 3-5 saat, \%14,1 (92)'si 1 saatten az, \%8,1 (53) 7 saatten fazla ve son olarak, \%5,5 (36)'s1 5 ila 7 saat arasinda internette zaman geçirdikleri anlaşılmıştır.

Çalışmaya katılan öğrencileri Sosyal Medya kavramını bilme durumları sorulmuştur. Alınan cevaplara bakıldığında; \%97,4 öğrenci sosyal medyayı bildiklerini, \%0,3'ü sosyal medya kavramını bilmediğini, \%2,3 ise sadece duyduklarını belirtmişlerdir. Öğrencileri sosyal ağları (facebook, netlog, myspace, orkut, yonja vb.) kullanıp kullanmadıkları sorulmuş, katılımcıların \%95,4 (621)'i sosyal ağları kullandıklarını, \%4,6'sı (30) kullanmadıklarını ifade etmişlerdir.

Çalışmaya katılan öğrencileri sosyal ağları kullanıyorlarsa en fazla hangisinde zaman geçirdikleri sorulmuştur. Öğrencilerden \%87,3 (568)'i facebook'u kullandığını, \%21,5'i (140) 
twitter'1 kullandığı anlaşılmıştır. \%4,8 (31) msn'i kullandığını, \%6,1'i (45) diğer seçeneğini tercih etmiştir. Çalışmaya katılan öğrencilerin \%79 (514) sosyal ağları her gün kullandıklarını, \%18,3 (119)'ü haftada 3-4 gün, \%2,3 (15)'i ayda bir iki gün ve \%0,5 (3)'i 3-4 ayda bir sosyal ağları kullandıklarını ifade etmişlerdir.

Öğrencilerin \%45,3'ü (295) profilini güncellemek için, \%38,3'ü (249) İnteraktif olmayan oyunları oynamak için sosyal ağları kullandığı anlaşılmıştır. \%35,9'u (234) Online sohbet amaçlı kullandıklarını, \%17,8 (116) yeni arkadaşlar bulmak amacıyla sosyal ağları kullanmaktadırlar. \%17,4 (113)'ü arkadaşlarının ne yaptığını bakmak, ve \%16,7'si (109) interaktif oyunlar oynamak için ve \%7,2'si (47) zaman geçirmek amaciyla sosyal ağları kullandıkları tespit edilmiştir. Katılımcıların \%78,8'i (513) devamlı takip ettikleri en az bir blog olduğunu; \%21,2'si (138) takip ettikleri herhangi bir blog olmadığını belirtmiştir. \%36,6 (238) Öğrenci, iş ağlarında (linkedln, bizebiz, xing, pronected vb) herhangi bir profillerinin olduğunu, \%63,4 (413) öğrenci ise herhangi bir iş ağına ait profillerinin olmadığını ifade etmişlerdir. Sosyal ağlarda yeni kişilerle tanışılan platformlar olduğunu ve öğrencilere sanal ortamda tanışılan kişilerle yüz yüze görüşme yapıp yapmadıkları sorulmuştur. Buna göre, \%65,4 (426) katılımcı yüz yüze görüşme yapmadıklarını, \%34,6 (225) katılımcı ise sanal ortamda tanıştıkları kişilerle yüz yüze görüştüklerini belirtmişlerdir. Sosyal imleme (social bookmark) sitelerini öğrencilerin \%36,6 (238)'s1 kullanmakta iken, \%63,4'ü (413) kullanmadıklarını ifade etmişlerdir. Video paylaşım sitelerinde takip edenlerin oranı \%37,6 (245) iken takip etmeyenlerin oranı \%62,4 (406) olarak tespit edilmiştir. Yine bu soru ile bağlantılı olarak video paylaşım sitelerinde video paylaşıp paylaşılmadığ sorusu yöneltilmiştir. Buna göre \%67,5'i (439) video paylaştıklarını, \%32,6'sı (212) herhangi bir video paylaşmamışlardır.

Web 2.0 uygulamalarından olan fotoğraf paylaşım sitelerini takip eder misiniz? sorusuna öğrencilerin \%48,8'i (318) evet, \%51,2'si (333) hayır olarak cevaplamışlardır. Fotoğraf paylaşım sitelerinde, fotoğraf paylaşan öğrencilerin oranı \%67,0 (436), fotoğraf paylaşmayan öğrenciler oranı ise \%33,0 (215)' dür. Anlık ileti uygulamaları (msn, gtalk, yahoo, msn vb.) en az birini kullanan \%66,4 (432), kullanmadıklarını ifade eden öğrenci ise \%33,6 (219) dır. Çalışmaya katılan öğrencilerin \%70,0 (456)'i sosyal medyalarda yer alan içeriklere yorumlar yazdıklarını, \%30,0 (195)'u ise herhangi bir yorum yazmadıklarını belirtmişlerdir. Sosyal medyalarda markalarla ilgili içeriklere yazılan yorumlar o marka ile ilgili düşüncenizde bir farklılık yaratmakta mıdır? sorusuna \%51,8 (337) evet yaratmaktadır. \%32,4 (211)'ü hayır ve \%15,8 (103)'i bazen cevabını verdikleri görülmüştür. Öğrencilere "Sosyal Medyanın Öğrenim ve Öğretim Süreçlerine Etkisini Belirleme"'’ye yönelik yapılan ankette, öğrencilerin ankete verdikleri cevaplar tablo $4^{\prime}$ de verilmiştir. Buna göre;

"Sosyal medyanın eğitim amaçlı kullanımını faydalı bulmuyorum." ifadesine verilen cevapların ortalaması 2,65 olarak hesaplanmıştır. Katılımcıların cevapları "Kararsızım" 
yönünde ağırlık kazandığı söylenebilir. Çalışmanın konusu olan sosyal medyanın eğitim amaçlı kullanımının faydalı olmayacağı görüşü katılımcılar tarafından kararsız olarak cevaplanmıştır.

"Sosyal medyada deneyimli bir kullanıcı haline gelmek benim için çok kolay oldu." ifadesine verilen cevapların ortalaması 3,67 olarak hesaplanmıştır. Katılımcıların cevapları "Katılıyorum" yönünde ağırlık kazanmıştır. Katılımcıların, Sosyal medyayı kullanım şekillerinde deneyimli olduklarını ifade etmektedirler.

"Eğitimim sırasında ulaştı̆̆ım internet erişim imkanları, sosyal medyayı kullanmamı kolaylaştırıyor." ifadesine verilen cevapların ortalaması 3,57 olarak hesaplanmıştır. Katılımcıların cevapları "Katılıyorum" yönünde ağırlık kazanmıştır.

Ölçekte yer alan sorulardan 1 ile 9. sorular "Sosyal medyanın eğitim süreçlerindeki önemi" 10-16 arası sorular "sosyal medyanın eğitimde kullanımını etkileyen faktörleri", 17-20 arası sorular "sosyal medyayı eğitimde kullanmaya yönelik tutumları" ve son olarak 21-22. sorular "sosyal medyanın kulanım sıklığı"nı ölçmektedir. Tablo 4 incelediğinde;

I. bölümde "Sosyal medyanın eğitim süreçlerindeki önemi" ile ilgili sorularda katılımcılar sosyal medyanın eğitim amaçlı kullanımını faydalı bulup bulmama konusunda kararsız oldukları görülse de 2,65 ortalama ile katılıyorum cevabına yakın olduğu düşünülmektedir. Çünkü diğer sorularda, örneğin, ödevlerini yapmada, sosyal medya kullanımında deneyimli olduklarını, eğitimde sosyal medya kullanımını verimliliği arttırdığını ifade etmişlerdir.

II. bölümde "sosyal medyanın eğitimde kullanımını etkileyen faktörleri" incelendiğinde Ders öğretim görevlileri ve okul yöneticileri eğitim süreçlerinde sosyal medya araçlarının kullanımı konusunda katılımcıları teşvik ettikleri, Bir sosyal ağın üyesi ve kullanıcısı olmak, katılımcı açısından bir topluluğun parçası olduğu hissi uyandırdığı, Katılımcının sosyal ağ topluluğu ile arasındaki arkadaşlık ilişkileri ve birliktelik katılımcı için çok şey ifade ettiğini belirtmişlerdir.

III. bölümde "sosyal medyayı eğitimde kullanmaya yönelik tutumları" genel olarak öğrencilerin sosyal medyayı eğitimde kullanmaya yönelik tutumlarının olumlu olduğu söylenebilir. Katılımcılar eğitim etkinlerinde sosyal medyayı kullanmanın öğrenmelerine yardımcı olduklarını ifade etmektedirler.

Son olarak IV. Bölümde "Sosyal medyanın kulanım sıklığı" ile ilgili ifadeler incelediğinde, geçmiş öğretim yıllarında okullardaki eğitim etkinliklerinde sosyal medyayı sıklıkla kullandıklarını ve okulda ki eğitim süreçlerinde de sosyal medyayı bu öğretim yılında sıklıkla kullandıklarını ifade etmişlerdir. 
Tablo 4: Sosyal Medyanın Öğrenim ve Öğretim Süreçlerine Etkisini Belirleme

\begin{tabular}{|c|c|c|c|c|c|c|c|c|c|c|c|c|c|}
\hline \multirow{2}{*}{\multicolumn{2}{|c|}{$\begin{array}{c}\text { Sosyal Medyanın Öğrenim ve } \\
\text { Öğretim süreçlerine Etkisini } \\
\text { Belirleme }\end{array}$}} & \multicolumn{2}{|c|}{ 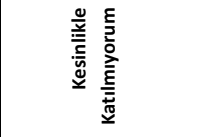 } & \multicolumn{2}{|c|}{ 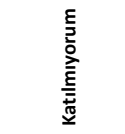 } & \multicolumn{2}{|c|}{ 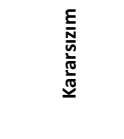 } & \multicolumn{2}{|c|}{ 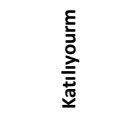 } & \multicolumn{2}{|c|}{ 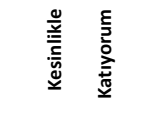 } & \multirow[t]{2}{*}{$\begin{array}{l}\stackrel{\pi}{E} \\
\frac{\pi}{\pi} \\
\stackrel{\mathbb{t}}{0}\end{array}$} & \multirow[t]{2}{*}{ 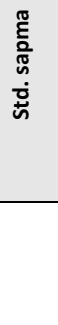 } \\
\hline & & f & $\%$ & $f$ & $\%$ & $f$ & $\%$ & $f$ & $\%$ & $f$ & $\%$ & & \\
\hline 1 & $\begin{array}{l}\text { Sosyal medyanın eğitim amaçlı kullanımını faydalı } \\
\text { bulmuyorum }\end{array}$ & 166 & 25,5 & 127 & 19,5 & 190 & 29,2 & 104 & 16,0 & 64 & 9,8 & $\mid 2,65$ & 1,284 \\
\hline 2 & $\begin{array}{l}\text { Eğitimde sosyal medyayı kullanmam, daha iyi } \\
\text { notlar almamı sağlıyor }\end{array}$ & 76 & 11,7 & 80 & 12,3 & 129 & $\begin{array}{l}19,8 \\
\end{array}$ & 233 & 35,8 & 133 & 20,4 & 3,41 & 1,265 \\
\hline 3 & \begin{tabular}{|l} 
Eğitimimde sosyal medyayı kullanmam, \\
ödevlerimi daha çabuk bitirmemi sağlıyor
\end{tabular} & 78 & 12,0 & 110 & 16,9 & 144 & \begin{tabular}{|l}
22,1 \\
\end{tabular} & 204 & 31,3 & 115 & 17,7 & 3,26 & 1,267 \\
\hline 4 & $\begin{array}{l}\text { Eğitimde sosyal medya kullanmak verimliliğimi } \\
\text { arttırıyor }\end{array}$ & 79 & 12,1 & 102 & 15,7 & 92 & $\begin{array}{l}14,1 \\
\end{array}$ & 248 & 38,1 & 130 & 20,0 & $\mid 3.38$ & 1,296 \\
\hline 5 & Sosyal medya kullanımı kolay buluyorum. & 68 & 10,4 & 85 & \begin{tabular}{|l|l}
13,1 \\
\end{tabular} & 86 & 13,2 & 260 & 39,9 & 152 & 23,3 & $\mid$\begin{tabular}{||l}
3,53 \\
\end{tabular} & 1,268 \\
\hline 6 & $\begin{array}{l}\text { Sosyal medyada deneyimli bir kullanıcı haline } \\
\text { gelmek benim için çok kolay oldu. }\end{array}$ & 68 & 10,4 & 57 & 8,8 & 71 & 10,9 & 280 & 43,0 & 175 & 26,9 & |3,67 & 1,250 \\
\hline 7 & $\begin{array}{l}\text { Sosyal medyanın eğitim amaçlı kullanımını } \\
\text { öğrenmeyi kolay buluyorum }\end{array}$ & 69 & 10,6 & 58 & 8,9 & 105 & 16,1 & 285 & 43,8 & 134 & 20,6 & $\mid$\begin{tabular}{||l}
3,55 \\
\end{tabular} & 1,215 \\
\hline 8 & $\begin{array}{l}\text { Sosyal medya uygulamalarını basit ve anlaşılır } \\
\text { buluyorum }\end{array}$ & 58 & 8,9 & 67 & 1,3 & 111 & 17,1 & 291 & 44,7 & 124 & 19,0 & $\mid$\begin{tabular}{||l}
3,55 \\
\end{tabular} & 1,171 \\
\hline 9 & $\begin{array}{l}\text { Eğitimim sırasında ulaştığım internet erişim } \\
\text { imkanları, sosyal medyayı kullanmamı } \\
\text { kolaylaştırıyor }\end{array}$ & 60 & 9,2 & 57 & 8,8 & 117 & 18,0 & 284 & 43,6 & 133 & 20,4 & 3,57 & 1,176 \\
\hline 10 & $\begin{array}{l}\text { Derslerimize giren öğretim görevlileri ve } \\
\text { okulumuzun yöneticileri eğitim süreçlerinde } \\
\text { sosyal medya araçlarının kullanımı konusunda bizi } \\
\text { teşvik ediyorlar }\end{array}$ & 49 & 7,5 & 90 & \begin{tabular}{|l|l}
13,8 \\
\end{tabular} & 130 & \begin{tabular}{|l|l}
20,0 \\
\end{tabular} & 273 & 41,9 & 109 & 16,7 & $\mid$\begin{tabular}{||l}
3,47 \\
|
\end{tabular} & 1,146 \\
\hline 11 & $\begin{array}{l}\text { Ailem ve akrabalarım eğitim sürecimde sosyal } \\
\text { medyayı kullanmamın gerekli olduğunu } \\
\text { düşünüyorlar. }\end{array}$ & 84 & 12,9 & 155 & 23,8 & 149 & 22,9 & 200 & 30,7 & 63 & 9,7 & 3,00 & 1,204 \\
\hline 12 & $\begin{array}{l}\text { Arkadaşlarım eğitim sürecimde sosyal medyayı } \\
\text { kullanmamın gerekli olduğunu düşünüyorlar. }\end{array}$ & 69 & 10,6 & 133 & 20,4 & 150 & \begin{tabular}{|l|l} 
& 23,0
\end{tabular} & 215 & 33,0 & 84 & 12,9 & 3,17 & 1,203 \\
\hline 13 & $\begin{array}{l}\text { Bir sosyal ağın üyesi ve kullanıcısı olmak, bende } \\
\text { bir topluluğun parçası olduğum hissi uyandırıyor. }\end{array}$ & 54 & 8,3 & 111 & 17,1 & 125 & $\begin{array}{l}19,2 \\
\end{array}$ & 268 & 41,2 & 93 & 14,3 & 3,36 & 1,165 \\
\hline 14 & $\begin{array}{l}\text { Bir sosyal medya topluluğuna bağlı olduğumu } \\
\text { hissediyorum. }\end{array}$ & 69 & 10,6 & 108 & 16,6 & 107 & $\begin{array}{l}16,4 \\
\end{array}$ & 254 & 39,0 & 113 & 17,4 & $\mid 3,36$ & 1,244 \\
\hline 15 & $\begin{array}{l}\text { Eğer bir ders çalş̧ma konusuyla ilgili olarak bir } \\
\text { cevap almaya ihtiyaç duyarsam, üye olduğum } \\
\text { sosyal medya grubuna çözüm ile ilgili cevap } \\
\text { almak için mesaj atabiliyorum. }\end{array}$ & 77 & 11,8 & 129 & $\begin{array}{l}19,8 \\
\end{array}$ & 108 & $\begin{array}{l}16,6 \\
\end{array}$ & 244 & 37,5 & 93 & 14,3 & 3,23 & 1,253 \\
\hline 16 & $\begin{array}{l}\text { Benim sosyal ağ topluluğumla aramdaki } \\
\text { arkadaşlı ilişkileri ve birliktelik benim için çok } \\
\text { şey ifade ediyor. }\end{array}$ & 54 & 8,3 & 118 & 18,1 & 125 & $\begin{array}{l}19,2 \\
\end{array}$ & 263 & 40,4 & 91 & 14,0 & 3,34 & 1,168 \\
\hline 17 & $\begin{array}{l}\text { Bana göre, geleneksel eğitim yöntemlerine ilave } \\
\text { olarak sosyal medyanın öğretim etkinliklerinde } \\
\text { kullanımın daha çok çekici olduğunu } \\
\text { düşünüyorum. }\end{array}$ & 63 & 9,7 & 120 & $\begin{array}{l}18,4 \\
\end{array}$ & 169 & $\begin{array}{l}26,0 \\
\end{array}$ & 218 & 33,5 & 81 & 12,4 & 3,21 & 1,168 \\
\hline 18 & $\begin{array}{l}\text { Geleneksel eğitim yöntemlerine ilave olarak sosyal } \\
\text { medyanın öğretim etkinliklerinde kullanımın çok } \\
\text { daha iyidir. }\end{array}$ & 51 & 7,8 & 89 & $\begin{array}{l}13,7 \\
\end{array}$ & 173 & 26,6 & 257 & 39,5 & 81 & 12,4 & 3,35 & 1,105 \\
\hline 19 & $\begin{array}{l}\text { Eğitim etkinliklerinde sosyal medyayı } \\
\text { kullanmaktan hoşlanıyorum. }\end{array}$ & 49 & 7,5 & 83 & $\begin{array}{ll}12,7 \\
\end{array}$ & 145 & 22,3 & 285 & 43,8 & 89 & 13,7 & 3,43 & 1,108 \\
\hline
\end{tabular}




\begin{tabular}{|c|c|c|c|c|c|c|c|c|c|c|c|c|c|}
\hline 20 & $\begin{array}{l}\text { Eğitim etkinlerinde sosyal medyayı kullanmak } \\
\text { ögrenmeme yardımcı oluyor }\end{array}$ & 46 & 7,1 & 78 & 12,0 & 111 & 17,1 & 317 & 48,7 & 99 & 15,2 & 3,53 & 1,104 \\
\hline 21 & $\begin{array}{l}\text { Geçmiş öğretim yıllarında Okulunuzdaki eğitim } \\
\text { etkinliklerinde sosyal medyayı skklıkla kullandık. }\end{array}$ & 53 & 8,1 & 91 & 14,0 & 132 & 20,3 & 281 & 43,2 & 94 & 14,4 & 3,42 & 1,141 \\
\hline 22 & $\begin{array}{l}\text { Okulunuzdaki eğitim süreçlerinizde sosyal } \\
\text { medyayı bu öğretim yılında sıklıkla kullandık. }\end{array}$ & 62 & 9,5 & 115 & 17,7 & 127 & 19,5 & 260 & 39,9 & 87 & 13,4 & 3,30 & 1,185 \\
\hline
\end{tabular}

Öğrencilerin eğitim süreçlerinde kullanılan sosyal medya araçlarına ilişkin veri analiz sonuçları incelendiğinde, öğrenciler tarafından eğitim süreçlerinde en fazla Sosyal Ağ Web sitelerinin (Facebook, MySpace, Bebo, LinkedIn, Google+, vb.) kullanıldığı gözlenmektedir. E-portfolio ya da dijital portfolio çalışmaların, sertifikaların ve kanıtların elektronik ortamda kullanıcı tarafından toplanmasıdır. Çalışmaya katılan öğrencilerin \%85,4 e-portfolio kullanmadıklarını belirtmişlerdir. Yine Delicious, (sosyal imleme) sık kullanılan internet sitesi bağlantılarını depolamak, paylaşmak ve yeni siteleri keşfetmek için sık kullanılan bir yoldur. Delicious herkese açık olup, sık kullandığınız linkleri, makaleleri, blogları müzikleri saklayabilir ve herhangi bir bilgisayardan rahatlıkla ulaşabilirsiniz. Sık kullanımlarınızı paylaşabildiğiniz bir sitedir. Katılımcıların \%83,9'u bu aracı kullanmadıklarını ifade etmişlerdir. Sonuçlar tablo 5'de verilmiştir.

Tablo 5: Eğitimde Kullanılan Sosyal Medya Araçları

\begin{tabular}{|c|c|c|c|c|c|}
\hline \multirow{2}{*}{\multicolumn{2}{|c|}{ Eğitim Süreçlerinde Kullanılan Sosyal Medya Araçları }} & \multicolumn{2}{|c|}{ Kullanıyorum } & \multicolumn{2}{|c|}{ Kullanmiyorum } \\
\hline & & f & $\%$ & f & $\%$ \\
\hline 1 & Web Seminerleri & 172 & 26,4 & 479 & 73,6 \\
\hline 2 & Podcast araçları & 149 & 22,9 & 502 & 77,1 \\
\hline 3 & E-portfolyolar & 95 & 14,6 & 556 & 85,4 \\
\hline 4 & Anlık Mesajlaşma Araçları & 262 & 40,2 & 389 & 59,8 \\
\hline 5 & $\begin{array}{l}\text { Sosyal Ağ websiteleri (Facebook, MySpace, Bebo, } \\
\text { Linkedln, Google }+ \text { vb.) }\end{array}$ & 519 & 79,7 & 132 & 20,3 \\
\hline 6 & Wikiler & 409 & 62,8 & 242 & 37,2 \\
\hline 7 & Teletop & 181 & 27,8 & 470 & 72,2 \\
\hline 8 & Delicious & 105 & 16,1 & 546 & 83,9 \\
\hline 9 & YouTube & 291 & 44,7 & 360 & 55,3 \\
\hline 10 & Diğgerleri & 491 & 75,4 & 160 & 24,6 \\
\hline
\end{tabular}

Öğrencilerin sorulara verdikleri yanıtların frekans analiz sonuçları incelendiğinde, öğrencilerin eğitim amaçlı olarak sosyal ağlar içinde en çok kullandıkları web sitesinin Facebook olduğu görülmektedir. "Sconex" ve "windows of life" kullanımının daha az olduğu görülmektedir. Sonuçlar Tablo 6' da verilmiştir. 
Tablo 6: Öğrencilerin Eğitimde Kullandıkları Sosyal A $\breve{g}$ Web Siteleri

\begin{tabular}{|c|c|c|c|c|c|}
\hline & \multirow{2}{*}{$\begin{array}{c}\text { Eğitimde Kullanılan Sosyal A } \breve{g} \text { Web } \\
\text { Siteleri }\end{array}$} & \multicolumn{2}{|c|}{ Kullanıyorum } & \multicolumn{2}{|c|}{ Kullanmiyorum } \\
\hline & & f & $\%$ & $\mathrm{f}$ & $\%$ \\
\hline 1 & Bobo & 291 & 44,7 & 360 & 55,3 \\
\hline 2 & Facebook & 566 & 86,9 & 85 & 13,1 \\
\hline 3 & Friendster & 355 & 54,5 & 296 & 45,5 \\
\hline 4 & Linkedln & 100 & 15,4 & 551 & 84,6 \\
\hline 5 & MySpace & 133 & 20,4 & 518 & 79,6 \\
\hline 6 & Sconex & 113 & 17,4 & 538 & 82,6 \\
\hline 7 & Windows life Space & 113 & 17,4 & 538 & 82,6 \\
\hline 8 & Yahoo! 360 & 183 & 28,1 & 468 & 71,9 \\
\hline 9 & Google + & 342 & 52,5 & 309 & 47,5 \\
\hline 10 & Diğer & 508 & 78,0 & 143 & 22,0 \\
\hline
\end{tabular}

Analiz sonuçlarına göre, öğrencilerin sosyal ağ web sitelerini "fotoğraf, müzik, video ya da diğer çalışmaları paylaşmak için" kullandıkları sonucu ortaya çıkmıştır. Ardından "ders konularıyla ilgili olarak sınıf arkadaşlarımla iletişim kurmak" ve "arkadaşlarımla bağlantı kurmak için" sosyal ağ web sitelerini kullandıklarını belirtmişlerdir. Sonuçlar Tablo 7'de verilmiştir.

Tablo 7: Sosyal A $\breve{g}$ Web Sitelerinin Kullanım Amaçları

\begin{tabular}{|c|c|c|c|c|c|}
\hline & \multirow[t]{2}{*}{ Sosyal Ağ Web Sitelerinin Kullanım Amaçları } & \multicolumn{2}{|c|}{ Kullaniyorum } & \multicolumn{2}{|c|}{ Kullanmiyorum } \\
\hline & & $\mathrm{f}$ & $\%$ & $\mathrm{f}$ & $\%$ \\
\hline 1 & Arkadaşlarımla bağlantı kurmak için & 504 & 77,4 & 147 & 22,6 \\
\hline 2 & Hiç tanışmadığım kişilerle yeni arkadaşlıklar kurmak için & 482 & 74,0 & 169 & 26,0 \\
\hline$\frac{2}{3}$ & $\begin{array}{l}\text { İnsanlar hakkında daha fazla bilgi edinmek için (Daha önce } \\
\text { tanıdığım ya da tanımadığım) }\end{array}$ & 353 & 54,2 & 298 & 45,8 \\
\hline 4 & Bir forum ortamında fikirlerimi ve görüşlerimi paylaşmak için & 480 & 73,7 & 171 & 26,3 \\
\hline 5 & Web sitesi reklamlarına cevap vermek için & 338 & 51,9 & 313 & 48,1 \\
\hline 6 & Herhangi birisiyle randevulaşıp buluşmak için & 203 & 31,2 & 448 & 68,8 \\
\hline 7 & Etkinlikleri planlamak ya da arkadaşlarımı davet etmek için & 342 & 52,5 & 309 & 47,5 \\
\hline 8 & $\begin{array}{l}\text { Ders konularıyla ilgili olarak öğretim görevlileriyle iletişim } \\
\text { kurmak için }\end{array}$ & 472 & 72,5 & 179 & 27,5 \\
\hline 9 & $\begin{array}{l}\text { Ders konularıyla ilgili olarak sınıf arkadaşlarımla iletişim } \\
\text { kurmak için }\end{array}$ & 521 & 80,0 & 130 & 20,0 \\
\hline 10 & Fotoğraf, müzik, video ya da diğer çalıșmaları paylașmak için & 578 & 88,8 & 73 & 11,2 \\
\hline 11 & Mesleğimle ilişkili etkinlikler için (iş ağları, vb) & 502 & 77,1 & 149 & 22,9 \\
\hline 12 & Özel ilgi, hobi gruplarına katılmak için & 489 & 75,1 & 162 & 24,9 \\
\hline 13 & Diğer & 460 & 70,7 & 191 & 29,3 \\
\hline
\end{tabular}

Öğrencilerin sosyal medyanın eğitim süreçlerindeki önemi ölçeğinde yer alan üç boyut kendi içerisinde toplanarak o boyuttaki soru sayısına bölünmüştür. Böylelikle her bir öğrencinin boyutlara verdikleri ortalama puanlar elde edilmiştir. Birinci boyutta güvenirliklik Cronbach's Alpha 0,881, İkinci boyutta güvenirlilik Cronbach's Alpha 0,814, üçüncü boyutta güvenirlilik Cronbach's Alpha 0,815, dördüncü boyutta güvenirlilik Cronbach's Alpha 0,693 olarak belirlenmiştir. Çalışmanın bu kısmında boyutlarla ilgili kullanılan kısaltmalar aşağıda belirtilmiştir.

ORTEO: Sosyal Medyanın Eğitim Süreçlerinde Önemi 
ORTEF: Sosyal Medyanın Eğitimde Kullanımını Etkileyen Faktörler

ORTT: Sosyal Medyanın Eğitimde Kullanmaya Yönelik Tutumları

Öğrencilerin eğitim süreçlerinde sosyal medya kullanımları, eğitimde kullanılan sosyal medya araçlarından, sosyal ağ web sitelerinin kullanılması ve kullanım amaçlarına göre farklılık olup olmadığı ortalama skorlar üzerinden incelenmiştir. Bunun için ortalama skorların öncelikle normal dağılım gösterip göstermediği Kolmogorov-Smirnov ve ShapiroWilk istatistiklerine göre araştırılmış boyutlara ait ortalama skorlar normal dağılmadığı belirlenmiştir $(\mathrm{P}<0,05)$. Dolayısıyla farklılıklar araştııllırken parametrik testler yerine nonparametrik testlere başvurulacaktır.

Öğrencilerin cinsiyete göre sosyal medyanın öğrenim ve öğretim süreçlerine etkisini belirlemeye yönelik algılamaları arasında fark olup olmadığı her üç boyut için MannWhitney U testi ile araştırılmış iki boyutta fark bulunmuştur. Buna göre; Öğrencilerin sosyal ağların eğitimde önemini üzerine yönelik algılamalarında istatistiksel açıdan anlamlı fark bulunmuştur ( $\mathrm{z}=-1,97 ; \mathrm{p}=0,049)$. Buna göre kadın öğrencilerin sosyal ağların eğitimde olan önemi daha yüksek bulunmuştur.

Öğrencilerin sosyal ağların eğitimde kullanım etkilerine yönelik algılamaları arasında fark olup olmadığı Mann-Whitney U testi ile araştırılmış ve iki boyutta fark bulunmuştur. Buna göre kadın öğrencilerin sosyal ağların eğitimde önemine yönelik algısı daha yüksek bulunmuştur( $z=-1,966 ; p=0,049)$. Benzer şekilde kadın öğrencilerin eğitimde sosyal medyanın kullanımını etkileyen faktörler algısı daha yüksek bulunmuştur( $z=-2,154 ; p=0,031)$. Öğrencilerin cinsiyetine göre sosyal ağların eğitimde kullanım tutumları arasında fark yoktur( $\mathrm{z}=-1,154 ; \mathrm{p}=0,079)$. Sonuçlar tablo 8 'de verilmiştir.

Tablo 8: Cinsiyet ve Sosyal Medyanın Öğrenim ve Öğretim Süreçlerine Etkisini

Belirlemeye Yönelik Algılamaları

\begin{tabular}{|c|c|c|c|c|c|c|}
\hline Boyutlar & Cinsiyet & $\mathrm{N}$ & Ortalama & Std. Sapma & $z$ & $p$ \\
\hline \multirow{2}{*}{ ORTEO } & kadın & 431 & 3,4599 & ,82728 & \multirow[t]{2}{*}{$-1,966$} & \multirow{2}{*}{,049 } \\
\hline & erkek & 220 & 3,2717 & 99081 & & \\
\hline \multirow{2}{*}{ ORTEF } & kadın & 431 & 3,3255 & 81463 & \multirow[t]{2}{*}{$-2,154$} & \multirow{2}{*}{,031 } \\
\hline & erkek & 220 & 3,1760 & 83317 & & \\
\hline \multirow{2}{*}{ ORTT } & kadın & 431 & 3,4246 & ,87178 & \multirow[t]{2}{*}{$-1,754$} & \multirow{2}{*}{,079 } \\
\hline & erkek & 220 & 3,2920 & 94826 & & \\
\hline
\end{tabular}




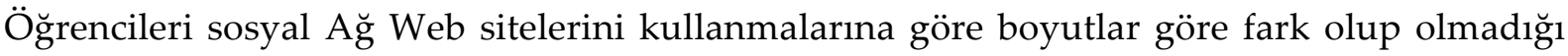
Mann-Whitney U testi ile araştırılmıştır. Buna göre, tüm boyutlarda farklılık bulunmuştur. Buna göre, sosyal ağ web sitelerini kullanan öğrencilerin sosyal ağların eğitimde olan önemi daha yüksek bulunmuştur $(z=-2,337 ; p=0,019)$. Benzer şekilde sosyal ağ web sitelerini kullanan öğrencilerin sosyal medyanın eğitimde olan faktörleri algılaması daha yüksek bulunmuştur $(z=-2,668 ; p=0,008)$. Son olarak sosyal ağ web sitelerini kullanan öğrencilerin sosyal medyanın eğitimde kullanım tutumları daha yüksek bulunmuştur $(z=-2,906 ; p=0,004)$. Sonuçlar tablo 9'da verilmiştir.

Tablo 9: Sosyal Medyanın Öğrenim ve Öğretim Süreçlerine Etkisini Belirlemeye Yönelik Algılamalar ile Sosyal Medya Araçlarını Kullanmaya Yönelik Algılamaları

\begin{tabular}{|c|c|c|c|c|c|c|}
\hline Boyutlar & $\begin{array}{c}\text { Sosyal Ağ Web Siteleri } \\
\text { (facebook,myspace,google+ vd.) }\end{array}$ & $\mathrm{N}$ & Ortalama & $\begin{array}{l}\text { Std. } \\
\text { Sapma }\end{array}$ & $z$ & $\mathrm{p}$ \\
\hline \multirow{2}{*}{ ORTEO } & kullanıyorum & 519 & 3,4414 & ,86838 & \multirow[t]{2}{*}{$-2,337$} & \multirow{2}{*}{,019 } \\
\hline & kullanmıyorum & 132 & 3,2189 & 95156 & & \\
\hline \multirow{2}{*}{ ORTEF } & kullanıyorum & 519 & 3,3187 & 81690 & \multirow[t]{2}{*}{$-2,668$} & \multirow{2}{*}{,008 } \\
\hline & kullanmıyorum & 132 & 3,1028 & ,82912 & & \\
\hline \multirow{2}{*}{ ORTT } & kullanıyorum & 519 & 3,4311 & ,88187 & \multirow[t]{2}{*}{$-2,906$} & \multirow{2}{*}{,004 } \\
\hline & kullanmıyorum & 132 & 3,1780 & 94381 & & \\
\hline
\end{tabular}

Öğrencilerin sosyal ağlardan wikileri kullanıp kullanmamasına göre, sosyal medyaya verdikleri önemlerin üç boyut için farklılaşıp, farklılaşmadığı Mann-Whitney U testi ile araştırılmıştır. Her üç boyutta da fark bulunmamıştır. Sonuçlar tablo 10' da verilmiştir.

Tablo 10: Sosyal Medyanın Öğrenim ve Öğretim Süreçlerine Etkisini Belirlemeye Yönelik Algılamalar ile Sosyal Medya Araçlarını Kullanmaya Yönelik Algılamaları

\begin{tabular}{|c|c|c|c|c|c|c|}
\hline Boyutlar & Wikiler & $\mathrm{N}$ & Ortalama & Std. Sapma & $z$ & $p$ \\
\hline \multirow{2}{*}{ ORTEO } & kullanıyorum & 409 & 3,3727 & ,87298 & \multirow[t]{2}{*}{$-1,486$} & \multirow{2}{*}{, 0137 } \\
\hline & kullanmıyorum & 242 & 3,4362 & 91755 & & \\
\hline \multirow{2}{*}{ ORTEF } & kullanıyorum & 409 & 3,2913 & ,81347 & \multirow[t]{2}{*}{$-0,368$} & \multirow{2}{*}{, 0713 } \\
\hline & kullanmıyorum & 242 & 3,2473 & 84076 & & \\
\hline ORTT & kullanıyorum & 409 & 3,3869 & ,86366 & $-3,13$ & , 0754 \\
\hline
\end{tabular}




\begin{tabular}{|l|l|l|l|l|}
\hline kullanmiyorum & 242 & 3,3678 &, 95954 & \\
\hline
\end{tabular}

Öğrencilerin sosyal ağ web sitesi (facebook) kullanıp kullanmamasına göre, sosyal medyaya verdikleri önemlerin üç boyut için farklılaşıp, farklılaşmadığı her üç boyut için MannWhitney U testi ile araştırılmıştır. Her üç boyutta da fark bulunmamıştır. Sonuçlar tablo $11^{\prime}$ de verilmiştir.

Tablo 11 : Sosyal Medyanın Öğrenim ve Öğretim Süreçlerine Etkisini

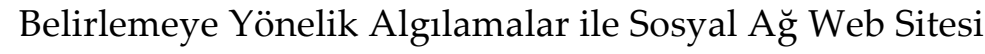
(facebook) Kullanımına Yönelik Algılamaları

\begin{tabular}{|c|c|c|c|c|c|c|}
\hline Boyutlar & Facebook & $\mathrm{N}$ & Ortalama & Std. Sapma & $\mathrm{z}$ & $p$ \\
\hline \multirow{2}{*}{ ORTEO } & kullanıyorum & 566 & 3,3954 & ,88390 & \multirow[t]{2}{*}{$-0,255$} & \multirow{2}{*}{,0799 } \\
\hline & kullanmıyorum & 85 & 3,4026 & ,93230 & & \\
\hline \multirow{2}{*}{ ORTEF } & kullanıyorum & 566 & 3,2832 & ,82300 & \multirow[t]{2}{*}{$-0,569$} & \multirow{2}{*}{,0569 } \\
\hline & kullanmıyorum & 85 & 3,2202 & ,82848 & & \\
\hline \multirow{2}{*}{ ORTT } & kullanıyorum & 566 & 3,3931 & ,88875 & \multirow[t]{2}{*}{$-1,143$} & \multirow{2}{*}{,0253 } \\
\hline & kullanmıyorum & 85 & 3,2912 & 97120 & & \\
\hline
\end{tabular}

Sosyal medyanın öğrenim etkisi ile web siteleri kullanım amaçları arasında fark olup olmadığı her üç boyut için Mann-Whitney U testi ile araştırılmıştır. Her üç boyutta da anlamlı fark bulunmuştur. Öğrencilerin Ders konuları ile ilgili olarak sınıf arkadaşlarımla iletişim kurmak için sosyal ağları kullanıp kullanmamaya göre, sosyal medyanın eğitim süreçlerindeki etkisi algılamaları arasında fark bulunmuştur.

Buna göre, öğrencilerin ders konuları ile ilgili olarak sınıf arkadaşları ile iletişim kurmak için sosyal ağları kullananların sosyal medyanın eğitimde önemi algısı daha yüksek bulunmuştur ( $\mathrm{z}=--, 3523 ; \mathrm{p}=0,000)$.

Öğrencilerin ders konuları ile ilgili olarak sınıf arkadaşları ile iletişim kurmak için sosyal ağları kullananların sosyal medyanın eğitimde kullanımını etkileyen faktörlere algısı daha yüksek bulunmuştur ( $z=-3,298 ; p=0,001)$. Öğrencilerin ders konuları ile ilgili olarak sınıf arkadaşları ile iletişim kurmak için sosyal ağları kullananların, sosyal medyanın eğitimde kullanmaya yönelik tutumları daha yüksek bulunmuştur $(\mathrm{z}=-3,959 ; \mathrm{p}=0,0001)$. Sonuçlar tablo 12 'de verilmiştir. 
Tablo 12: Sosyal Medyanın Öğrenim ve Öğretim Süreçlerine Etkisini Belirlemeye Yönelik Algılamalar ile Sosyal A $\breve{g}$ Web Sitelerinin Kullanım Amaçlarına Yönelik Algılamaları

\begin{tabular}{|c|c|c|c|c|c|c|}
\hline Boyutlar & $\begin{array}{c}\text { Ders konuları ile ilgili } \\
\text { olarak sınıf } \\
\text { arkadaşlarımla iletişim } \\
\text { kurmak }\end{array}$ & $\mathrm{N}$ & Ortalama & Std. Sapma & $z$ & $p$ \\
\hline \multirow[t]{2}{*}{ ORTEO } & kullanıyorum & 521 & 3,4487 & 89415 & \multirow[t]{2}{*}{$-3,523$} & \multirow[t]{2}{*}{,000 } \\
\hline & kullanmıyorum & 130 & 3,1863 & ,84237 & & \\
\hline \multirow{2}{*}{ ORTEF } & kullanıyorum & 521 & 3,3208 & ,82205 & \multirow[t]{2}{*}{$-3,298$} & \multirow{2}{*}{,001 } \\
\hline & kullanmıyorum & 130 & 3,0912 & ,80577 & & \\
\hline \multirow{2}{*}{ ORTT } & kullanıyorum & 521 & 3,4458 & ,88432 & \multirow[t]{2}{*}{$-3,959$} & \multirow{2}{*}{,000 } \\
\hline & kullanmıyorum & 130 & 3,1154 & 91613 & & \\
\hline
\end{tabular}

Öğrencilerin sosyal ağları meslekleri ile ilgili etkinlikler için kullanıp kullanmamaya göre, sosyal medyanın eğitim süreçlerindeki etkisi her üç boyut içinde araştırılmış ve farklılıklar bulunmuştur. Buna göre, sosyal ağları meslekleri ile ilgili etkinlikler için kullanan öğrencilerin sosyal medyanın eğitimdeki önemi algısı daha yüksek bulunmuştur ( $\mathrm{z}=-, 3481$; $\mathrm{p}=0,0001)$.

Öğrencilerin sosyal ağları meslekleri ile ilgili etkinlikler için kullanıp kullanmamaya göre, sosyal medyanın eğitimde kullanımını etkileyen faktörlere algısı daha yüksek bulunmuştur(5,384; $\mathrm{p}=0,0001)$.

Öğrencilerin sosyal ağları meslekleri ile ilgili etkinlikler için kullanıp kullanmamaya göre, sosyal medyanın eğitimde kullanmaya yönelik tutumları algısı daha yüksek bulunmuştur $(\mathrm{z}=-4,105 ; \mathrm{p}=0,0001)$. Sonuçlar tablo 13'de verilmiştir.

Tablo 13: Sosyal Medyanın Öğrenim ve Öğretim Süreçlerine Etkisini Belirlemeye Yönelik Algılamalar ile Sosyal A ̆ Web Sitelerinin Kullanım Amaçlarına Yönelik Algilamaları

\begin{tabular}{|c|c|c|c|c|c|c|}
\hline Boyutlar & $\begin{array}{c}\text { Mesleğimle ilişkili } \\
\text { etkinlikler için (iş } \\
\text { ağları) }\end{array}$ & $\mathrm{N}$ & Ortalama & Std. Sapma & z & $p$ \\
\hline ORTEO & kullanıyorum & 502 & 3,4655 & ,86356 & $-3,481$ & ,000 \\
\hline
\end{tabular}




\begin{tabular}{|c|c|c|c|c|c|c|}
\hline & kullanmıyorum & 149 & 3,1633 & ,93842 & & \\
\hline \multirow[t]{2}{*}{ ORTEF } & kullanıyorum & 502 & 3,3668 & ,80076 & \multirow{2}{*}{$-5,384$} & \multirow[t]{2}{*}{,000 } \\
\hline & kullanmıyorum & 149 & 2,9655 & ,82562 & & \\
\hline \multirow{2}{*}{ ORTT } & kullanıyorum & 502 & 3,4577 & ,87880 & \multirow{2}{*}{$-4,105$} & \multirow{2}{*}{,000 } \\
\hline & kullanmıyorum & 149 & 3,1174 & ,92294 & & \\
\hline
\end{tabular}

\section{Sonuç ve Öneriler}

Yapılan çalışmada Çanakkale Onsekiz Mart Üniversitesi, Çanakkale Sosyal Bilimler Meslek Yüksekokulunda okumakta olan 1140 öğrenciden çalışmaya dahil olan 651 öğrencinin internet kullanım alışkanlıkları, sosyal medyayı bilme düzeyleri, sosyal medya kullanım alışkanlıkları ve sosyal medyayı eğitim süreçlerinde kullanımlarını incelenmiştir. Yapılan analizler sonucunda ortaya çıan sonuçlar şunlardır:

- İnterneti resmi amaçla kullanırım \%67,3; download \%50,1, Bankacıllk \%44,3, eğlence \%31,0, Sosyal ağlar \%25,7, bilgi alışverişi (hobi, haber,ödev vb.) \%20,4, video izleme 1\%18,8 olarak tespit edilmiştir.

- \%79,4'ü her gün interneti kullandıklarını, \%19,2 haftada 3-4 gün internet kullandıklarını ayda bir iki gün kullanan katılımc1 \%1,2 ve 3-4 ayda bir interneti kullanırım diyen katılımc1 sayısı ise $\% 0,21$ 'dir.

- Sosyal Medyayı \%97,4 (634)'ü bildiklerini, \%3 (2)'ü bilmediklerini ve \%2,3 (15) sadece duyduklarını ifade etmişlerdir

- Katılımcıların \%95,4 (621)'i sosyal ağları kullandıklarını, \%4,6 (30) katılımcı kullanmadıklarını ifade etmişlerdir.

- Öğrencilerden \%87,3 (568)'i facebook kullanmaktadırlar. \%21,5 (140)'1 twitter kullanmaktadırlar.

- Çalışmaya katılan öğrencilerin \%79 sosyal ağları her gün kullandıklarını ifade etmişlerdir.

- Katılımcıların \%78,8 devamlı takip ettikleri en az bir blog olduğunu belirtmişlerdir.

- Çalışmaya katılan öğrencilerin \%70,0 (456)'i sosyal medyalarda yer alan içeriklere yorumlar yazdıklarını ifade etmişlerdir.

- Sosyal medyalarda markalarla ilgili içeriklere yazılan yorumlar o marka ile ilgili düşüncenizde bir farklılık yaratmakta mıdır? sorusuna \%51,8 öğrenci evet demektedir. 
- Sosyal medyanın eğitim süreçlerinde kullanımının faydalı olduğu, kullandıkça deneyim sahibi oldukları, ödevlerini yapmada kolaylıklar yaşadıklarını, sosyal medya uygulamalarını basit ve anlaşılır bulduklarını, öğretim elemanlarının ve okul yönetiminin sosyal medya kullanımında teşvik edici oldukları, geleneksel yöntemlere ilave sosyal medyanın öğretim etkinliklerinde kullanımının daha etkili olduğunu, eğitim etkinliklerde sosyal medya kullanmanın daha çekici olduğunu ifade etmişlerdir.

Çalışmaya katılan öğrencilerin sosyal medya araçlarını kullandıklarını, özellikle facebook ve wikilerin çalışma kapsamındaki katılımcılar tarafından sıklıkla kullanıldığ Katılımcıların eğitimde kullandıkları sosyal ağ web sitelerinde facebook ve friendster tercih ettikleri görülmektedir. Sosyal Ăg web sitelerinin kullanım amaçları incelediğinde web sitelerini Fotoğraf, müzik, video ya da diğer çalışmaları paylaşmak için, ders konularıyla ilgili olarak sınıf arkadaşları ile iletişim kurmak ve arkadaşları ile bağlantı kurmak için" sosyal ağ web sitelerini kullanmakta oldukları sonucuna ulaşılmıştır.

Değişkenler ile yapılan analiz sonuçları incelendiğinde; Öğrencilerin cinsiyete göre sosyal medyanın öğrenim ve öğretim süreçlerine etkisini belirlemeye yönelik algılamaları arasında fark olup olmadığı her üç boyut için Mann-Whitney U testi ile araştırılmış iki boyutta fark bulunmuştur. Buna göre; Öğrencilerin sosyal ağların eğitimde önemini üzerine yönelik algılamalarında istatistiksel açıdan anlamlı fark bulunmuştur. Buna göre kadın öğrencilerin sosyal ağların eğitimde olan önemi daha yüksek bulunmuştur.

Öğrencilerin sosyal ağların eğitimde kullanım etkilerine yönelik algılamaları arasında fark olup olmadığı Mann-Whitney U testi ile araştırılmış ve iki boyutta fark bulunmuştur. Buna göre kadın öğrencilerin sosyal ağların eğitimde önemine yönelik algısı daha yüksek bulunmuştur. Benzer şekilde kadın öğrencilerin eğitimde sosyal medyanın kullanımını etkileyen faktörler algısı daha yüksek bulunmuştur. Öğrencilerin cinsiyetine göre sosyal ağların eğitimde kullanım tutumları arasında fark yoktur. Öğrencileri sosyal A $\breve{g}$ Web sitelerini kullanmalarına göre boyutlar göre fark olup olmadı̆̆ı Mann-Whitney U testi ile araştırılmıştır. Buna göre, tüm boyutlarda farklılık bulunmuştur. Buna göre, sosyal ağ web sitelerini kullanan öğrencilerin sosyal ağların eğitimde olan önemi daha yüksek bulunmuştur. Benzer şekilde sosyal ağ web sitelerini kullanan öğrencilerin sosyal medyanın eğitimde olan faktörleri algılaması daha yüksek bulunmuştur.

Sosyal ağ web sitelerini kullanan öğrencilerin sosyal medyanın eğitimde kullanım tutumları daha yüksek bulunmuştur. Öğrencilerin sosyal ağlardan wikileri kullanıp kullanmamasına göre, sosyal medyaya verdikleri önemlerin üç boyut için farklılaşıp, farklılaşmadığı MannWhitney U testi ile araştırılmıştır. Her üç boyutta da fark bulunmamıştır. Öğrencilerin sosyal ağ web sitesi (facebook) kullanıp kullanmamasına göre, sosyal medyaya verdikleri önemlerin üç boyut için farklılaşıp, farklılaşmadığı her üç boyut için Mann-Whitney U testi ile araştırılmıştır. Her üç boyutta da fark bulunmamıştır. 
Sosyal medyanın öğrenim etkisi ile web siteleri kullanım amaçları arasında fark olup olmadığı her üç boyut için Mann-Whitney U testi ile araştırılmıştır. Her üç boyutta da anlamlı fark bulunmuştur. Öğrencilerin Ders konuları ile ilgili olarak sınıf arkadaşlarımla iletişim kurmak için sosyal ağları kullanıp kullanmamaya göre, sosyal medyanın eğitim süreçlerindeki etkisi algılamaları arasında fark bulunmuştur.

Buna göre, öğrencilerin ders konuları ile ilgili olarak sınıf arkadaşları ile iletişim kurmak için sosyal ağları kullananların sosyal medyanın eğitimde önemi algısı daha yüksek bulunmuştur.

Öğrencilerin ders konuları ile ilgili olarak sınıf arkadaşları ile iletişim kurmak için sosyal ağları kullananların sosyal medyanın eğitimde kullanımını etkileyen faktörlere algısı daha yüksek bulunmuştur. Öğrencilerin ders konuları ile ilgili olarak sınıf arkadaşları ile iletişim kurmak için sosyal ağları kullananların, sosyal medyanın eğitimde kullanmaya yönelik tutumları daha yüksek bulunmuştur. Öğrencilerin sosyal ağları meslekleri ile ilgili etkinlikler için kullanıp kullanmamaya göre, sosyal medyanın eğitim süreçlerindeki etkisi her üç boyut içinde araştırılmış ve farklılıklar bulunmuştur. Buna göre, sosyal ağları meslekleri ile ilgili etkinlikler için kullanan öğrencilerin sosyal medyanın eğitimdeki önemi algısı daha yüksek bulunmuştur.

Öğrencilerin sosyal ağları meslekleri ile ilgili etkinlikler için kullanıp kullanmamaya göre, sosyal medyanın eğitimde kullanımını etkileyen faktörlere algısı daha yüksek bulunmuştur.Öğrencilerin sosyal ağları meslekleri ile ilgili etkinlikler için kullanıp kullanmamaya göre, sosyal medyanın eğitimde kullanmaya yönelik tutumları algısı daha yüksek bulunmuştur. Yapılan anket ve buna bağlı olarak sonuçlar değerlendirildiğinde sonuç olarak, sosyal medya kavramının öğrenciler tarafından bilinirliliği arttırma ve kullanımına yönelik derslerde ve ders dışı etkinliklerinde öğrencilere (seminer, çalıştay, proje, ödev vb.) bilgi verilmesi gerektiği düşünülmektedir.

Sosyal medyanın sadece bir profil oluşturup, fotoğraf bakıp, beğenmenin ötesinde bir uygulama olduğu bilinci geliştirilmelidir. Öğretim elemanlarının dijital yerli (Dijital çağda doğup büyüyen genç nesil bireylere) denilen dijital çağın öğrencilerine, kendilerini sürekli yenilemeleri gerektiğini öğretmeleri gerekmektedir. Araştırma da göstermektedir ki dijital göçmenlerin (Dijital dünya ile sonradan tanışanlar) verdikleri geleneksel eğitim anlayışı, dijital yerliler için yeterli olmadığı görülmektedir. Ders kapsamında, bölüm kapsamında sosyal ağlar oluşturulup eğitim ve öğretim sadece sınıfta sınırlandırılmayıp hazırlanan sosyal ağlarda da elektronik ortamda devam edilmelidir. Yine ders kapsamında bloglar hazırlanabilir. Youtube-edu, google-jokey, Google Maps, prezi, sadece eğitsel amaçlı kullanılan Teacher Tube, Çeşitli internet sayfalarında yayınlanan haber, makale, fotoğraf, video, ses ve günlüklerden oluşan içeriğin, RSS adı verilen teknoloji vb. gibi web 2.0 uygulamalarının kullanımı, paylaşımı, katılımın sağlanması ile öğreten ve öğrenenin 
mekansal birlikteliği gerekmeksizin, sanal dünyada buluşmaları, projeler, yeni fikirler, farklı ortamların yaratıldığı eğitim süreçleri oluşturulmalıdır. Web 2.0 uygulamaları dünya da yerini artık web 3.0 bırakmaktadır. Değişim hızla ilerlemektedir. Bu değişim öğretim elemanları tarafından fark edilmeli ve hızla uyum sağlanmalıdır. Öğretim elemanları öğrencilere bu konularda da örnek olmalı, böylelikle eğitimin kalitesinin de yükselmesine katkı sağlayacağı düşünülmelidir. Bu katkı ile nitelikli mezun öğrenciler yetiştirilebileceği düşünülmektedir.

\section{Kaynakça}

Baran, Bahar; Ata, Fiğen. (2013). Üniversite Öğrencilerinin Web 2.0 Teknolojileri Kullanma Durumları, Beceri Düzeyleri ve Eğitsel Olarak Faydalanma Durumları, Eğitim ve Bilim Dergisi, Cilt 38, Sayı 169

Bozkurt, Aras (2013). Açık ve Uzaktan Öğretim: Web 2.0 ve Sosyal Ağların Etkileri, Akademik Bilişim konferansı, Akdeniz Üniversitesi (http://ab.org.tr/ab13/bildiri/211.pdf)

Deperlioğlu, Ömer; Köse, Utku. (2010). Web 2.0 Teknolojilerinin Eğitim Üzerindeki Etkileri ve Örnek Bir Öğrenme Yaşantısı, Akademik Bilişim Sempozyumu,

Durusoy, Okan. (2011). Öğretmen Yetiştirmede Web 2.0 ve Dijital Video Teknolojilerinin Kullanılarak Öğretmenlik Öz-Yeterlilik Geliştirilmesi, Yükseklisans tezi, Balıkesir Üniversitesi, Fen Bilimleri Enstitüsü, Bilgisayar ve Öğretim teknolojileri Eğitimi Anabilimalı

Elmas, Rıdvan; Geban, Ömer. (2012). 21 . Yüzyıl Öğretmenleri için web 2.0 Araçları, International Online Journal of Education Sciences, 4(1), JOJES

Erkul, R. Erdem. (2009). Sosyal Medya Araçlarının ( Web 2.0 ) Kamu Hizmetleri ve Uygulamalarında Kullanılabilirliği, Türkiye Bilişim Derneği Aralik 2009, Sayı 116

Genç, Zülfü. (2010). Web 2.0 Yeniliklerin Eğitimde Kullanımı: Bir Facebook Eğitim Uygulaması, Akademik Bilişim Konferansı, Muğla Üniversitesi

Horzum, Mehmet Barış. (2010), Öğretmenlerin Web 2.0 araçlarından haberdarlığı, kullanım sıklıkları ve amaçlarının çeşitli değişkenler açısından incelenmesi, “Uluslar arası İnsan Bilimleri Dergisi, Cilt 7, sayı: 1

İşlek, Mahmut Sami, (2012). Sosyal Medyanın Tüketici Davranışlarına Etkileri: Türkiye'deki Sosyal Medya Kullanıcıları Üzerine Bir Araştırma, Yükseklisans tezi, KAramanoğlu Mehmetbey Üniversitesi, İşletme Anabilimdalı

Uçak, Özenç Nazan; Çakmak, Tolga. (2010). Hacettepe Üniversitesi Bilgi ve Belge Yönetimi Öğrencilerinin Web 2.0 Araçlarını Kullanım Özellikleri, 2. Uluslararası Değişen Dünyada Bilgi Yönetimi Sempozyumu, 22-24 Eylül 2010, Ankara

Sağır, Gülhan. (2011). "Tüketicilerin Kurumsal Sosyal Sorumluluk Uygulamalarını Algılaması", Yükseklisans Tezi, İnönü Üniversitesi Sosyal Bilimler Enstitüsü, İşletme Anabilimdalı Üretim Yönetimi ve Pazarlama Bilim Dalı 
Toğay, Abdullah; Akdur, T. Akdur; Yetişken, İ. Cihan; Bilici, Arzu, (2013). Eğitim Süreçlerinde Sosyal Ağların Kullanımı: Bir MYO Deneyimi, Akademik Bilişim Konferansı, Akdeniz Üniversitesi

Vural, Beril. Bat, Mikail (2010). Yeni bir iletişim ortamı olarak sosyal medya: ege üniversitesi iletişim Fakültesine yönelik bir araştırma "Journal of Yasar University" 20(5)

http://www.bidb.itu.edu.tr/?d=641

http://eogrenme.anadolu.edu.tr/eKitap/sos206u.pdf

http://e-bergi.com/2007/Aralik/Social-Network

http://sbe.kmu.edu.tr/userfiles/file/tezler/isletme/mahmutsamii\%C5\%9Flek.pdf

http://www.kurumsalhaberler.com/pr/sosyal-medya-nedir.aspx

http://www.digitaldevlet.org/web2.0.pdf 
AJIT-e: Online Academic Journal of Information Technology

2014 Spring/Bahar - Cilt/Vol: 5 - Sayı/Num: 15

DOI: 10.5824/1309-1581.2014.2.002.x 